\title{
General Atomics Enhances Pre-College Science Education
}

General Atomics (GA) is committed to playing a major role in enhancing precollege science education in the San Diego area as well as for the nation. The program includes "hands-on" teaching units to provide an innovative and interesting format for the teaching of scientific concepts as well as other activities designed to bring the industrial research experience into the classroom.

The GA education outreach program originated from a desire on the part of the CEO of GA, Neal Blue, his wife Anne Blue, and Patricia Winter, GA's education outreach coordinator, to initiate a program to enrich $\mathrm{K}-12$ science education in the San Diego area. This was inspired by a similar successful program that Anne and Patricia started in biology at the neighboring Salk Institute. GA's education outreach coordinator, senior management, and science administrators from the San Diego area brought together teams of GA scientists and junior and senior high school science teachers from San Diego County to formulate hands-on teaching units. The teams consisted of at least four scientists and four teachers. Over the course of a year, they developed five teaching modules based on active areas of research at GA: An Exploration of Materials Science, Radioactivity in the Environment, Energy from the Atom, Fusion, and Recombinant DNA. These workshops have been presented to over 300 teacher attendees from junior and senior high schools in the local area. Recently, the materials science module was presented to teachers in Orange County, California, and it was also presented as part of an American Chemical Society nationwide satellite television seminar for science teachers.

The teaching module for the Exploration of Materials Science was developed because this science field is not generally taught at the pre-college level, and its multidisciplinary nature allows it to be taught as part of physics, chemistry, or biology classes. The module includes elements of chemistry, physics, mathematics, engineering, and the use of computers.

The teaching module enables students to produce, study, characterize, and compare different classes of materials: metals, ceramics, and polymers. The students begin by fabricating test bars of materials characteristics from each of the three general classes. Tin was selected for the metal because of its ready availability, low melting temperature, and nontoxic nature. Test bars are fabricated by melting tin on a hot plate and casting it into a graphite mold. An anchor cement was selected as the ceramic to allow the use of a roomtemperature cure. The samples are cast into a plastic mold using a mold release. A one-part ultraviolet-curable polyester resin was selected for the representative polymer material because of its simplicity, ease of curing, and relative nontoxicity. The polymer samples are made by casting them into a mold with a release agent and curing them for a few minutes in direct sunlight. The students characterize the properties of each of the materials by noting their general appearance and performing a series of experiments to measure their mechanical properties, thermal and electrical conductivity, density, corrosion resistance, and high temperature behavior.

The teaching module is designed to give the teacher maximum flexibility. It can be used in full or in part at any grade level in junior through senior high school. Parts of it are even usable at the primary school level. Teachers have adapted it for classroom segments of anywhere between a few days and several weeks. The content can be extended into more advanced topics for science projects or advanced placement classes.

The teachers using this module often set the students up in groups since the multidisciplinary aspects of the experiments lend themselves to a team approach. The students are encouraged to think and solve problems as a team. For example, one team fabricates one of the types of materials, measures its physical properties and becomes the class expert in this type of material. The team members then write a report in the same format that a scientist would write a scientific paper. Teachers are encouraged to use this method so that students can emulate the industrial team approach to solving problems. Many of the teachers use the material to introduce concepts such as the scientific method, basic laboratory tech-

The Education Exchange highlights the experiences of scientists and engineers with local schools, along with helpful hints and resources. If you would like to share your own involvement in science education, contact: MRS Bulletin, 9800 McKnight Road, Pittsburgh, PA 15237-6006; fax 412-367-4373; e-mail Bulletin@mrs.org. niques, data analysis, scientific notation, and significant digits.

Since materials science is not wellknown to most teachers, all teachers who wish to obtain and use this unit must attend a 2-3 hour presentation. These presentations have been held about once every five months at GA and local education conferences. The classes are taught on weekends by both the GA scientists and the San Diego area teachers who developed the module, so that teacher attendees learn the material from both the scientific and the educational experts. In a typical class, the attending teachers listen to the experiences of those who have taught the unit at both the senior and junior high school levels. The attendees watch demonstrations in order to learn how to set up the laboratory apparatus and perform the experiments. The experimental kit is then discussed in detail.

The experimental kit contains both a laboratory and a print kit. The print kit includes the experimental procedure for fabricating and testing the samples, and a list of questions for the students. It provides detailed guides, written by the scientists, that cover preparation, mechanical properties, transport properties, and physical properties of materials and their relationship to the experiments performed in the module. Suggested objectives, strategies, and time frames are provided by the teachers who developed the unit. Recent popular articles on materials science from newspapers and magazines are included along with two videos on materials science: a Dow Corning sponsored PBS series called "The Stuff of Dreams" and Digital Equipment sponsored PBS show entitled "Miracles by Design."

The laboratory kit contains all the materials and equipment needed to perform the experiments that would not be found in the typical science classroom. The raw materials for making the test specimens are provided. The kit also includes graphite molds used to form the rod-shaped specimens. The means to reorder materials is also provided.

The kits are given to the teachers free of charge. Some of the materials in the kits are donated by companies while others have been purchased or provided by GA. The GA scientists and San Diego teachers met after hours and on weekends to develop the module and do the same when they demonstrate the kits to the teachers.

Students have responded favorably to the materials science module. An eighth grade earth science teacher spent three 
weeks using the module and said that her students "loved the experiments and felt that they were doing real science." A chemistry senior remarked that the preparation of the test bars was the most fun that she had ever had in a classroom. Others in the class said that "it was something that was real and interesting and cool. It was about tangible things that you could relate to in every day life."

GA is also involved in other forms of education outreach. It holds a High School Science Day each year. This program opens with talks by senior management, continues with visits to two of 12 different GA facilities and laboratories, and concludes with a panel discussion on science as a career. Other activities include school visits to the DIII-D tokamak fusion facility as part of the GA Fusion Education Program, many K-12 education activities at the GA-operated San Diego Supercomputer Center, and Partnerships in Education with various San Diego city schools.

For further information about the GA education outreach program, please contact Patricia Winter at General Atomics, 3550 General Atomics Court, Mail Stop 1/109, San Diego, CA 92121-1194; phone (619) 455-3335; fax (619) 455-3379; e-mail winters@vaxd.gat.com.

LaWrence WoOlF and Terrry GULdeN

Lawrence Woolf has a PhD in Physics from the University of California, San Diego. $\mathrm{He}$ is currently manager of the high-temperature superconductivity program at General Atomics, a high technology company located in San Diego, California. He has been involved in various aspects of the GA education outreach program and was a member of the team that developed the Materials Science Teaching Module. His address is General Atomics, Mail Stop 2-442, 3550 General Atomics Court, San Diego, CA 92121-1194; phone (619) 455-4475; fax (619) 455-4268; e-mail woolfl@vaxd.gat.com.

Terry Gulden has a PhD in Materials Science from Stanford University. He is currently Director of Advanced Materials Technology at General Atomics. Gulden has been active in the GA education outreach program and was team leader for the development of the Materials Science Teaching Module. His address is General Atomics, 3550 General Atomics Court, San Diego, CA 92121-1194; phone (619) 455-2893; fax (619) 455-4268; e-mail gulden@vaxd.gat.com.

To receive additional information on how you can get involved in enhancing $\mathrm{K}-12$ science education, circle number 120 on the Reader Service Card.

\section{A Solid Resource for Fundamental Materials Science}

From Academic Press

\section{Engineering Materials Science}

\section{Milton Ohring}

This comprehensive, introductory textbook will provide undergraduate engineering students with the fundamental background needed to understand the science of structure-property relationships, as well as address the engineering concerns of materials selection in design, processing materials into useful products, and how material degrade and fail in service. Specific topics include: physical and electronic structure; thermodynamics and kinetics; processing; mechanical, electrical, magnetic, and optical properties; degradation; and failure and reliability.

Key Features

- Provides a modern treatment of materials exposing the interrelated themes of structure, properties, processing, and performance

- Includes and interactive, computationally oriented, computer disk containing nine modules dealing with structure, phase diagrams, diffusion, and mechanical and electronic properties

- Fundamentals are stressed

CONTENTS (Chapter Headings): Introduction to Materials Science and Engineering. Electrons in Solids and Their Role in Bonding. Structure of Solids. Polymers, Glasses, Ceramics, and Non-Metallic Mixtures. Thermodynamics of Solids. Kinetics of Mass Transport and Phase Transformations. Mechanical Behavior of Solids. Materials Processing and Forming Operations. Engineering Materials; How They Are Strengthened and Toughened. Degradation and Failure of Structural Materials. Electrical Properties of Metals, Insulators, and Dielectrics. Semiconductor Materials and DevicesóScience and Technology. Optical Properties of Materials. Magnetic Properties of Materials. Failure and Reliability of Electronic Materials and Devices.

Seplember 1995 , c. 848 pp., \$64.95 (tentative)/ISBN: 0-12-524995-0

\section{Physics of Thin Films}

\section{Advances in Research and Development}

Volume 18: Plasma Sources for Thin Film Deposition and Etching

Edited by Maurice H. Francombe and John L. Vossen

1994, 328 pp., \$95.00/ISBN: 0.12.533018-9

Circle No. 4 on Reader Service Card.

\section{Order from your local bookseller or directly from}

(AP) Academic Press, Inc. Order Fulfillment Dept. DM27098

6277 Sea Harbor Drive, Orlando, FL 32887 24-28 Oval Road, London NW1 7DX, U.K.
In the U.S. and Canada Call Toll Free: 1-800-321-5068 Fax: 1-800-336-7377 E-mail: ap@acad.com In Europe, Call: 0181-300-3322
Prices subject to change without notice. $\odot 1995$ by Academic Press, Inc. All Rights Reserved. NS/JEMG/PECS -26075

\section{Send Bulletin News To:}

Editor, MRS Bulletin

Materials Research Society

9800 McKnight Road, Pittsburgh, PA 15237-6006

Fax (412) 367-4373 